\title{
The impacts of individualization on equity educational policies
}

\author{
Guadalupe Francia* \\ Department of Education, Uppsala University, Sweden \{guadalupe.francia@ped.uu.se \\ Received on 12 October 2012; revised on 12 October 2012; accepted on 19 October 2012; published on 15 January 2013
}

DOI: 10.7821/naer.2.1.17-22

\begin{abstract}
The present article has as its aim to illustrate and discuss the impacts of individualization strategies on equity educational policies through the analysis of individualized teaching strategies applied within the framework of educational priority policies in Sweden. The methodology used in our research work includes: (a) the study of research literature about the individualization of teaching implemented in the Swedish comprehensive compulsory school; and (b) the study of research literature about educational priority policies aimed at children from socially and ethnically segregated areas. Comparative research of educational policies considers the individualization of teaching carried out in the Swedish comprehensive compulsory school as a relevant explanation for the successful application of equitable educational policies in that country. However, research studies published during the 2000s in Sweden show a more complex perspective regarding the effects of individualized teaching strategies. This contribution reviews European comparative research studies on individualization strategies followed in the context of equity policies. It raises questions about the lack of analyses referring to the impacts of individualization on schools located in socially and ethnically segregated areas. It argues that this ideology tends to reduce the issue of school failure to ethnic segregation and individualized teacher support. This article claims that individualization strategies based on differentiated curricula for students run the risk of increasing the discrimination of students for reasons of language or ethnic background. Even though the present study focuses on the Swedish experience, it can lead to a better understanding of the impacts caused by individualization strategies on equity in other European countries.
\end{abstract}

KEYWORDS: EDUCATIONAL POLICY, CURRICULUM, CHILDREN'S RIGHTS, SOCIAL MOBILITY, SOCIAL DIFFERENCES

\section{INDIVIDUALIZATION AS AN EQUITY POLICY STRATEGY}

European Comparative research (Dupriez \& Dumay 2004; Mons, 2007) considers the integrated school model with automatic promotion implemented in the Scandinavian educational systems the most effective model for an equitable education policy. Furthermore, in the opinion of scholars such as Mons (2007), the individualization teaching strategies implemented in these educational systems have strongly

\footnotetext{
*To whom correspondence should be addressed:

Uppsala University

Department of Education

Box 2136

se-75002 Uppsala

Sweden
}

contributed to equity within this school model.

However, research studies published in the 2000s in Sweden (Dovemark, 2004; Vinterek, 2006; Francia \& Moreno Herrera, 2008; Skolverket, 2009a) show a more complex perspective regarding the effects of individualized teaching strategies on equity. Comparative Education research on Education priority policies (Demeuse, Frandji, Pincemin, Greger, \& Rochex, [Eds.], 2008) confirms the risk of individualization strategies based on reduced and differentiated curricula for minority groups in different European countries. These curriculum designs have often dismissed the claim for some kind of minimum equal educational standard guaranteed on a national level.

This contribution discusses individualization ideology impacts on equity with a particular focus on the reduced and differentiated curricula for students of foreign origin. Seeking to illustrate these impacts, our article begins with a comprehensive overview of the individualization policy applied in Sweden. It also discusses research studies about differentiated curriculum practices according to students' ethnicity, their mother tongue, gender and religious background. Even though this analysis focuses on the Swedish experience, it can lead to a better understanding of the impacts caused by individualization strategies in other European countries and, consequently, contribute to European Comparative research on equity.

\section{FROM UNIFORMITY TO INDIVIDUALIZATION}

The introduction of a public common compulsory school system in 1962 can be considered the starting point and the foundation of educational equality policies in Sweden. The "one school for all students" educational model based on a strongly centralized steering and a vision of standardized equality aimed to reduce social, cultural and gender differences in education during the 1960s, 1970s and 1980s (Francia \& Moreno Herrera 2008). However, this homogeneized education model failed to take into account the cultural and individual differences among students and provide a truly equal education. Moreover, it regarded diversity in education as a problem and thus significantly hampered the integration and achievement of ethnic minorities (Sjögren, 1995; Lahdenperä, 1997). At the same time, this model functioned as an instrument for the legitimization of differences in students' academic performance (Wallin, 2002).

However, this uniform and standardized equality policy was interrupted by the neoliberal reform of the late 1980s. The replacement of the concept of equality with that of equity in the legal texts introduced by this reform can be seen as a measure to guarantee diversity in the Swedish educational system (Francia, 1999). The reform was based on a vision of democracy that 
proposed individual freedom and local democracy as central values for the Swedish society (Englund \& Quennerstedt, 2008). Therefore, in order to transfer power to the individuals, this reform introduces free choice, decentralization and privatization in the name of children's right to an equitable educational system. It additionally emphasizes the development of individualization as a strategy of respect for diversity and equity (Francia \& Moreno, 2008).

Even though this neoliberal education policy stipulated the same education compulsory goals for all students at the public and independent compulsory schools it emphasized the subordination of teaching to students' interests and needs in order to guarantee school success for every child. The current national curriculum for compulsory school introduced in 1994 and based on the pedagogical ideology of the children-driven curriculum stipulates the individualization of teaching. In that way, it legitimized the transfer of the educational process from teachers to students as a mechanism to increase students' levels of free choice and responsibility in their own educational process (Francia \& Moreno, 2008).

The considerable influence of John Dewey's as well as Jean Piaget's pedagogical theories in Sweden largely contributed to the development of a long educational tradition characterised by child-centered curricula and students' active participation in the educational process at Swedish schools (Bergqvist, 2005). However, since the end of the 1980s, postmodern influences have resulted in a development of a more extreme individualization ideology based on a curriculum driven by the children. According to Bergqvist (2005) these postmodern curricula emphasize students' self-control and responsibility with regard to the planning, execution and evaluation of their own school work. The traditional teaching process steered by teachers has been replaced with students' independent and individual work in this individualization ideology.

This individualization ideology has implied an adjustment of the learning contents, methods and environments not only to the students' needs, profiles and interests but also to their social, cultural and religious background (Vinterek, 2006). This adjustment is stipulated in the Curriculum for the Compulsory School System, the Preschool Class and the Leisure-time Centre, 2011, which states the following:

Teaching should be adapted to each pupil's circumstances and needs. It should promote pupils' further learning and knowledge acquisition based on their backgrounds, earlier experience, language and knowledge (page 11).

Individualization implied the transfer of responsibility for the student's educational process from teachers to students. This transfer is defined as goals for the Swedish school system:

The school must ensure that each pupil:

takes personal responsibility for their studies and working environment, (Curriculum for the Compulsory School System, the Pre-school Class and the Leisure-time Centre, 2011:17)

Individualization can be implemented in different areas such as "content, range, level, material, speed, method, or how the student's work shall be assessed". Nevertheless, the purpose of individualization strategies at the school practice is often unclear (Vinterek, 2006, p.14).

\section{INDIVIDUALIZATION AS AN EQUITY STRATEGY}

The curriculum for the Compulsory school clearly states that the national goals define the equity rules for all students at Swedish schools. Education should be equitable "regardless of where in the country it is provided." At the same time, the curriculum stipulates that equity means paying attention to each student's special needs and circumstances as well as to their different ways of attaining the educational goals (Curriculum for the Compulsory School System, the Preschool Class and the Leisure-time Centre 2011, p.10).

At the same time, the right to equity for all children and youth still represents a challenge in Sweden. The percentage of early school leavers increased from $7.7 \%$ in 2000 to $12.0 \%$ in 2007 (European Commission, 2008). The percentage of Swedish students not achieving the required goals for basic eligibility at national upper secondary school programmes has risen from 8.6\% in 1998 to $12.3 \%$ in the spring of 2012 (Skolverket, 2012).

Moreover, the Swedish National Board of Education (Skolverket, 2009a) presented a report which showed that the implementation of decentralization and individualization has resulted in worse academic results among Swedish students. Such strategies have even contributed to a more socially segregated and differentiated school system that hinders the implementation of the national curriculum goals at the school level. To this must be added that Education research studies (Francia, 2007a, 2007b; Gustafsson, 2004; Gustafsson, 2006, 2007; Gustafsson \& Myrberg, 2009; Högdin, 2007) reveal considerable differences in the interpretation of the national goals and qualification criteria at the school and municipal levels.

The extreme adjustment of compulsory education goals to students' background locally can result in a reduction of the knowledge level goals for underprivileged groups in Swedish society because of lower teacher expectations regarding those groups or as a way to avoid religious and ethnic conflicts with parents from religious and ethnic minorities (Francia, 2007a, 2007b, 2007c).

The individualization ideology which has characterized the Swedish Education Policy since the 1990s makes it difficult to offer variation in pedagogical methods. Individualized teaching has grown at the expense of group lessons led by the teacher and much of the relevance corresponding to teachers' direct teaching and instructions has been lost (Vinterek, 2006).

According to Vinterek (2006, p.16) the impacts of individualization on students' outcomes are difficult to evaluate at the school practice because “...in some cases individualization in a special way can favour some students but be unfair to others depending on students' different needs and the adjustment to existing circumstances".

Even Frykman (1998) criticized the Swedish school system for its strong emphasis on students' present ethnical, linguistic and social situation and for neglecting the teacher's role as an agent for students' social mobility. This strong individualization of teaching has transformed schools in "therapeutic places” with unclear educational rules and that contributes to deteriorate school learning environments. This demand to adapt educational contents to students' identity and different backgrounds has resulted in low expectations regarding both the education of children and their professional choices. Frykman argues that this strong individualization has proved especially disadvantageous to children from homes without an academic tradition and has 
thus contributed to a reduction of social mobility in Swedish Society.

According to Dovemark (2004), the effects caused by the child-driven curriculum ideology that has characterized the school system during the last few decades has hardly ever been evaluated in Sweden. This curricular ideology starts from the assumption that children are subjects with a natural capacity to choose, plan and evaluate their own educational process according to their own interests and needs. Therefore, it advocates the limitation of the role played by the teacher and the increase of children's independence as far as schoolwork is concerned. However, Dovemark (2004) points out that this curricular ideology has definitely had negative effects on equity for education. It has increased social differences between student groups because, when students assume responsibility for the educational process, they tend to choose their school goals and work according to their habits and social backgrounds.

\section{INDIVIDUALIZATION STRATEGIES AIMED AT STUDENTS OF FOREIGN ORIGIN}

Although the Swedish educational system could be considered one of the most effective with regard to academic achievement (Dupriez \& Dumay, 2004), the percentage of school failure for students of foreign origin remains considerable. Statistics of The Swedish National Agency for Education (Skolverket, 2009b, 2009c) showed that $24.5 \%$ of students with a foreign background had not reached eligibility for upper secondary school after compulsory school in relation of $8.8 \%$ of students with a Swedish background during the academic year $2008 / 2009$. Furthermore, $47 \%$ of students of foreign origin who had arrived in Sweden since 2000 were not eligible for upper secondary school at the spring term of 2009.

The overrepresentation of students with a foreign background in school failure statistics can be explained by the social background differences found in families of foreign families in the same manner as it could be explained by the worse socioeconomic status, the higher unemployment rate and a greater percentage of single-parent families. According to the Swedish National Agency for Education (Skolverket, 2005) the effect of foreign background on students' school results is minimal in relation to the effect caused by social background. However, the residence time in Sweden influences students' school results. The foreign background effect is relevant in students born outside Sweden who arrived in Sweden after school had started. For this group, school differences still persist and can even be aggravated at upper secondary education. These students need ongoing pedagogical support during both compulsory school and upper secondary school. Statistics even show that students of foreign origin living in disadvantaged neighbourhoods have the worst academic school results due to the concentration of social problems at ethnic and social ghettos.

As an equity policy measure, the regulations governing Swedish Compulsory School stipulate differentiated strategies in order to individualize and adjust curriculum contents to students' ethnic and linguistic background.

The subject "Mother Tongue" is an example of this differentiated curriculum strategy. Students with a mother tongue other than Swedish are entitled to study their own language in compulsory school as well as in upper secondary school. These children also have the right to support in their original language when learning other subjects, if they need it.
Participation in the study of their own language is voluntary but municipalities are obliged by law to organize such education (Skolverket, 2007a). According to statistics from The Swedish National Agency for Education (Skolverket, 2007b), the Mother Tongue tuition included 15\% of all students in Sweden during the 2005-2006 academic year. The three largest Swedish cities, namely: Stockholm, Gothenburg and Malmö have a majority of students who take part in this teaching. Among the group of students entitled to receive education in their language of origin, Somali-speaking students stand out with the highest participation (72.8\%) followed by those who speak Albanian (67.6\%), Arabic (66.5\%), Persian (64\%), Turkish (58.7\%) and Kurdish (55.9\%). Those having the lowest participation are English-speaking students (49.8\%) and those whose mother tongue is Finnish (42.5\%).

Another example of this differentiated curricular strategy was the introduction of Swedish as a second language (SSL) in 1995 as a subject for pupils with a foreign background whose mother tongue is not Swedish. This differentiated curricular measure sought the recognition of differences in the Swedish language learning process for students with Swedish as their second language. SSL, as a differentiated curriculum strategy aimed to help children of foreign origin to acquire the level of proficiency required to study their other school subjects in Swedish. According to the Swedish National Agency for Education, SSL has more or less the same achievement goals and proficiency requirements for SSL and for the subject "Swedish" (as a first language). SSL is equivalent to the curricular subject "Swedish" as regards the eligibility for admission to university or other post-secondary studies. The differences between these two curricular subjects are based on the first- versus second-language acquisition perspective adopted for its teaching. The right and opportunity to study SSL is guaranteed in both compulsory and upper secondary school. Among the group of students entitled to receive instruction in "Swedish as a second language", students who speak Somali show the highest participation (70.8\%), followed by those who speak Turkish (63.4\%), Kurdish (62.2\%), Arabic (60.5\%), Albanian (57.7\%) and Persian (41.9\%). Those having the lowest participation percentages are Englishspeaking students (22.8\%) and Finnish-speaking students (22.3\%) (Skolverket, 2007b).

Interestingly, those minority groups who have a higher participation in differentiated curricular subjects such as Mother tongue tuition and Swedish as a second language are equally the most strongly affected by socio-economic segregation in the Swedish society. For example, minorities speaking Somali, Arabic, Kurdish, Turkish and Persian are more affected by segregation in Swedish society than the Finnish and English minorities, who have the lowest level of participation in these curricular subjects. A report by the National Integration Agency shows that foreigners of African and Asian origin are affected by structural discrimination in working life (Integrationsverket, 2004). Employment rates among these ethnic groups are lower than those of people belonging to other ethnic groups irrespective of the time spent in Sweden, their education, marital status and gender.

Educational and social research (Francia \& Moreno, 2008; Gustafsson, 2004; Högdin, 2007) also reveals that several kinds of reduced curriculum content practices are implemented in teaching practices for the following subjects: Physical education and health; Music; Religion; and Sexual Education, in the Swedish multicultural school system. This research 
demonstrates the existence of reduced curricula according to pupils' gender and religious background that tend to decrease and reshape the national compulsory educational knowledge standards at the school level. In particular, it is necessary to develop educational policies that guarantee the right of girls in minority cultures to equitable education, when reduced and differentiated curriculum practices are implemented in the name of recognition for cultural and religious differences at the school level.

An analysis of the Educational Priority Strategies for Equity ${ }^{1}$ implemented in Sweden by the National Agency for School Development during the period 2003-2007 shows that the strategies targeting children from socially disadvantaged neighbourhoods were defined only as strategies against ethnic segregation. With ethnic segregation as a starting point, these Educational priority policies for Equity tend to implement educational actions which are mainly focused on the development of Swedish as a second language, Mother Tongue tuition, teaching of school subjects in one's own language or bilingual education. These improvement strategies are legitimated by research works which show that Mother Tongue education and Swedish as a second language teaching provide effective pedagogical support for students with foreign backgrounds. However, the analysis of statistics for students' academic results reveals that the percentage of academic achievement continues to be low in most of the municipalities where these Educational Priority actions have been implemented. Furthermore, these equity strategies lack a problematization of the negative effects derived from implementing different syllabuses and evaluation criteria for different groups of pupils at the school level (Francia \& Moreno, 2008).

An evaluation (Myndigheten för Skolutveckling, 2004) of the curricular subject Swedish as a second language additionally questions the existence of such a differentiated curricular strategy for the teaching of Swedish. This evaluation shows that students of foreign origin who follow the subject Swedish as a second language are affected to a greater extent by school failure than those who study Swedish as first language. It also showed that only a small proportion of those students have recently arrived in Sweden. This report also registered negative attitudes among students and parents towards the subject Swedish as a second language, which is often associated with discrimination and stigmatisation for this category of pupils.

According to OECD (2010), Swedish as a Second Language (SSL) education is not integrated into other pedagogical strategies targeted to pupils with a foreign background at school practice. OECD suggested the need to develop intercultural guidelines to support SSL teachers so that they can focus more and more on integrating the teaching of subject matters other than Swedish in their classes. This is advisable because international research as well as experiences from school practice in Sweden have shown that "cognitive skills and language proficiency develop hand in hand and students can learn the language most effectively when they are taught for a specific purpose. In addition, a recommendation is made to

\footnotetext{
${ }^{1}$ These equity priority policies were motivated by the poor academic outcome of students living in socially and ethnically segregated neighborhoods, and also responded to the unfavourable economic situation of the schools located there. These strategies mainly targeted students born outside Sweden or children born in Sweden whose parents had been born abroad. They were implemented in the hope of improving pupils' academic results in those school areas.
}

increase the teaching quality of Swedish, English, Mathematics and new technologies for these students at Swedish schools.

Measures focused on developing the instruction of Mother Tongue and Swedish as a Second Language pay attention to the first- versus second-language acquisition perspective in students' learning process. They are implemented as a strategy to improve learning of school contents by pupils (OECD, 2010). However, Mother Tongue and Swedish as A Second Language are strategically aimed in practice at the most disadvantaged social ethnic groups, for instance, children whose mother tongues are Somali, Albanian and Arabic. Instead, the minorities that are more integrated into Swedish Society do not take part in these differentiated curricular strategies to the same extent. It is therefore necessary to make a deeper political, educational and research analysis about the impacts of these differentiated curricular strategies starting with a focus on aspects such as social class and mother tongue before extending the teaching of different curricular subjects in the pupil's mother tongue (Francia \& Moreno, 2008).

\section{SUMMARY AND CONCLUSION}

The hegemonic centralized educational policy of the 1960s, 1970s and 1980s had been particularly detrimental to students from socially underprivileged ethnic minorities, since it failed to take into account the cultural and individual differences between students and did not provide a truly equal education for everyone. The educational model of "one school for all” based on the public school monopoly has paradoxically hampered the goal of cultural justice in practice.

In order to increase equity, the neoliberal educational reform of the 1990s introduced individualized teaching strategies based on the adjustment of curriculum contents and practices to students' profile and background as well as to their free choice. According to Mons' research (2007) the individualization strategies implemented in Sweden have been successful because they have strongly contributed to equity in the current integrated educational system. In particular, the individualised strategies aimed to develop the teaching of different curricular subjects in the student's mother tongue have become an effective strategy to improve both pupils' learning of school contents and equity (OECD, 2010).

At the same time, Swedish research (Dovemark, 2004; Vinterek, 2006; Francia \& Moreno, 2008; Skolverket, 2009a) shows that the individualized curriculum practices implemented during the 2000s have increased the differences in academic results between students. On the one hand, the demand to adjust curriculum contents and evaluation criteria to students' needs, interests and backgrounds tends to benefit children belonging to social groups with a high degree of social and cultural capital. On the other hand, these differentiated curriculum practices run the risk of creating low expectations in educational policy and practice with regard to students from neighbourhoods affected by social and ethnic segregation.

Furthermore, most of these individualization strategies start from the assumption that children are able to choose what to study and how, and where they would like to study it. Paradoxically, these strategies have increased inequalities in the Swedish educational system because of the impact of families' social and cultural capital on children's “own” choice.

The Educational Priority policies implemented by the Swedish National Agency for School Development during the period 2003-2007 were mainly focused on the reduction of school 
failure derived from ethnic segregation (Francia \& Moreno, 2008). This reduction of ethnic segregation has consequently resulted in a lack of discussion about the existence of a differentiated syllabus in the Swedish Language subject for Swedish citizens belonging to second and third generation immigrant groups. In these cases, the role played by students' social class, birthplace, and mother tongue in foreign students' academic results has often been neglected. Consequently, this limitation to ethnic and language segregation runs the risk of increasing social segregation. In this way, these Educational priority policies may work more as an Ethnification of socioeconomic inequalities than as Equity strategies.

Differentiated language curricula for students with a foreign background are often legitimized by science research showing differences in students' learning process of first- versus secondlanguage acquisition. However, statistics reveal differences in the implementation of such strategies depending on the socioeconomic situation of immigrant groups in Swedish Society. It is consequently necessary to perform a deeper analysis about the impacts of these differentiated curricular strategies starting with a focus on aspects such as pupils' social class and mother tongue before extending these strategies to subjects other than Swedish or Mother tongue.

In short, the analysis of research works devoted to the impacts of the individualization ideology on equity shows that a curricular policy oriented towards equity at compulsory school can only include individualization strategies which simultaneously assure a fair distribution of academic standards and intellectual skills for all students. Therefore, it is necessary to stress the need for a careful follow-up of the negative impacts on equity caused by the following individualization strategies:

- Individualization strategies that legitimate reduced curricula and lower knowledge standards for children coming from ethnic minorities and socially marginalized groups.

- Individualization strategies that do not take into account the impact resulting from the interaction of ethnicity, social class and gender.

- Individualization strategies that do not include the development of academic standards and intellectual skills for every child.

- Individualization strategies with no clear goals and evaluation measures.

Finally, it can be stated that, although comparative research (Mons, 2007) provides evidence that the individualization strategies implemented in Scandinavia have strongly contributed to equity, a deeper questioning of individualization as an equity strategy is still needed. In particular, the impacts of the neoliberal individualization policies based on differentiated curriculum strategies for students with a foreign background and their right to equitable education should be re-examined.

\section{REFERENCES}

Bergqvist, K. (2005). Planering av eget arbete - ett förändrat innehåll i undervisning. In E. Österlind (Ed.), Eget arbete -en kameleont $i$ klassrummet. Perspektiv på ett arbetssättt från förskola tillgymnasium. Lund: Studentlitteratur.

Dupriez, V. Y., \& Dumay, X. (2004). L’égalité dans les systèmes scolaries: effect école ou effet société?. Les Cahiers de Recherche en education et Formation, 31.Girsef: CPU.

Dovemark, M. (2004). Ansvar - flexibilitet - valfrihet. En etnografisk studie om en skola i förändring. Göterborg Studies in Educational Sciences.
Englund, T., \& Quennersterdt, A. (2008). Likvärdighetsbegreppet I svensk utbildningspolitik. In T. Englunnd, \& A. Quennerstedt (Eds.), Vadå likvärdihget? Studier i utbildningspolitisk språkanvändning (pp.7-35). Göterborg: Daidalos.

European Commission (2008, September). Progress Towards The Lisbon Objectives in Education and Training. Indicators and Training. Commission Staff Working Document. Retrieved from http://ec.europa.eu/education/lifelong-learningpolicy/doc/report08/report_en.pdf

Francia, G. (2007a). Religiösa friskolor, en fråga om rättvisa. In J. Berglund \& G. Larsson (Eds.), Religiösa friskolor $i$ Sverige: Historiska och nutida perspektiv. Lund: Studentlitteratur.

Francia, G. (2007b, April). The Negotiation of the Right of the Child to Education in the Name of Religion. Paper presented to the conference Religion on the Borders: New Challenges in the Academic Study of Religion Södertörn university College, 19-22.

Francia, G. (2007c, September). Dilemmas in the implementation of the children's right to Equity in Education in the Swedish Compulsory School. Paper presented to the ECER conference Contested Qualities of Educational Research, 19-22. Ghent, Belgium.

Francia, G. (1999). Policy som text och praktik. En analys av likvärdighetsbegreppet i 1990-talets utbildningsreform för det obligatoriska skolväsendet. Doctoral Thesis. Pedagogiska institutionen. Stockholms universitet.

Francia, G., \& Moreno Herrera, L. (2008). En Suède. Les politiques d'éducation prioritaire en période de décentralisation et d'individualisation. In M. Demeuse, D. Frandji, D. Greger, \& J-Y. Rochex (Eds), (n.d), Evolution des politiques d'éducation prioritaire en Europe. Conceptions, mises en œuvre, débats (pp.236-261). Lyon: Editions de INRP.

Frykman, J. (1998). Ljusnande framtid! Skola, social mobilitet och kulturellt identitet. Lund: Historiska Media.

Gustafsson, K. (2004). Muslimsk skola, svenska villkor. Akademisk avhandling. Bokförlag: Umeå.

Gustafsson, J. E. (2006). Barns utbildningssituation. Stockholm: Rädda Barnen.

Gustafsson, J. E. (2007). Kommentar. In A. Lindbom (Ed) (n.d.), Friskolorna och framtiden segregation, konstnader och effektivitet, (pp.119-126). Stockholm.

Gustafsson, J. E., \& Myrberg, E. (2009). Resursers betydelse för elevers resultat. In L. M. Olsson (Ed.) (n.d.), Vad påverkar resultaten $i$ svensk grundskola? (pp. 160-206). Stockholm: Skolverket.

Högdin, S. (2007). Utbildning på (o)lika villkor: om kön och etnisk bakgrund i grundskolan. Stockholm: Institutionen för socialt arbete, Stockholms universitet.

Integrationsverket (2004). Integrationsverkets årsredovisning 2004. Retrieved from http://www.temaasyl.se/Templates/Page.aspx?id=301

Lahdenperä, P. (1997). Invandrarbakgrund eller skolsvårigheter?: En Textanalytisk studie av åtgärdsprogramför elever med invandrarbakgrund. Stockholm: HLS.

Mons, N. (2007). Les nouvelles politiques éducatives. La France fait-elle les bons choix ?. Paris: Presses Universitaires de France.

Myndigheten för Skolutveckling (2004). Kartläggning av svenska som $\begin{array}{llll}\text { andraspråk. Dnr 2003:757. Retrieved from } & \text {. }\end{array}$ http://www.skolutveckling.se/digitalAssets/116334_defkartlaggmars 04.pdf

OECD (2010). OECD Reviews of Migrant Education. Sweden. Retrieved from http://www.oecd.org/dataoecd/45/40/44862803.pdf

Sjögren, A. (1995). En "bra" svenska, från rimligt krav till försvarsmekanism. Bidrag till IMER october. Det mångkulturella Sverige efter år 2000. rskning och framtidsvisioner.

Skolverket (2005). Elever med utländsk bakgrund. En sammanfattande bild Skolverket Raport 05:897. Retrieved from http://www.skolverket.se

Skolverket (2007a). Le système scolaire suédois Retrieved from: http www.skolverket.se/sb/d/376

Skolverket (2007b). Descriptive data on pre-school activities, schoolage childcare, schools and adult education in Sweden 2006, 283. Retrieved from http://www.skolverket.se/sb/d/356/a/1326

Skolverket (2009a). Vad påverkar resultaten i svensk grundskola? Kunskapsöversikt om betydelsen av olika faktorer. Retreived from http://www.skolverket.se/sb/d/2573/a/17272

Skolverket (2009b). Betyg i grundskolan läsår 2008/2009. Retrieved from http://www.skolverket.se/sb/d/1637

Skolverket (2009c). PM - En beskrivning av slutbetygen i grundskolan 2009. Retrieved from http://www.skolverket.se 
Skolverket (2012). Fler elever obehöriga till gymnasieskolan. Retrieved from http://www.skolverket.se/statistik-ochanalys/statistik/2.4290/2.4442/fler-elever- $\quad$ obehoriga-tillgymnasieskolan-1.160349

Vinterek, M. (2006). Individualisering i skolsammanhang. Forskning i focus $\mathrm{nr}$ 31. Myndigheten för skolutveckling. Retrieved from http://www.skolutveckling.se

Wallin, E. (2002). Jämlikhet, likvärdighet och individer i undervisning. Pedagogisk Forskning i Sverige, 7(3), 200-209. 